\title{
Analisis Pengaruh Perubahan Arus Kas dan Laba Akuntansi Terhadap Return Saham pada Perusahaan Berkapitalisasi Besar
}

\author{
Azilia Yocelyn ${ }^{1}$ \& Yulius Jogi Christiawan ${ }^{2}$ \\ 1Alumni Fakultas Ekonomi Universitas Kristen Petra Surabaya \\ ${ }_{2}^{2}$ Fakultas Ekonomi Universitas Kristen Petra Surabaya \\ Email: yulius@peter.petra.ac.id
}

\begin{abstract}
ABSTRAK
Penelitian ini bertujuan untuk mengetahui apakah informasi perubahan arus kas dan laba akuntansi digunakan oleh investor untuk mengambil keputusan investasi yang tercermin dari return saham yang akan diperoleh. Penelitian ini juga melibatkan variabel bebas yaitu arus kas operasi, arus kas investasi, arus kas pendanaan dan laba akuntansi. Sedangkan, return dihitung dengan menggunakan geometric mean. Analisis data menggunakan analisis regresi berganda. Penelitian dilakukan terhadap 97 perusahaan yang memiliki kapitalisasi besar yang terdaftar di Bursa Efek Indonesia pada tahun 2009-2010. Hasil penelitian menyimpulkan bahwa pengungkapan laba akuntansi berpengaruh signifikan terhadap return saham. Hal ini menandakan bahwa investor mempertimbangkan informasi laba akuntansi yang diungkapkan dalam laporan tahunannya untuk membuat keputusan. Sedangkan variabel bebas yang lainnya tidak terbukti secara signifikan berhubungan dengan return saham.
\end{abstract}

Kata kunci: Return saham, arus kas, laba akuntansi dan keputusan investasi.

\begin{abstract}
This study aims to examine whether the changes of cash flows and accounting profit, used by investors to make investment decision, reflected in the companies' stock return. There are four independent variables includes in this study, that is cash flows from operating, investing, and financing activities, as well as accounting profit. The stock return is calculated by using the geometric mean method. Multiple regression analysis is used to examine the data on the top 97 public companies (based on market capitalization catagory) listed in Indonesia Stock Exchange for period 2009-2010. The result reveals that accounting profit disclosure markedly affected the stock return. This implies that investors took into account the publication of accounting profit in their decision making. On the other side, the study cannot prove the association of other independent variables to the stock return.
\end{abstract}

Keywords: Stock return, cash flow, accounting profit and investment decisions.

\section{PENDAHULUAN}

Salah satu informasi penting untuk menilai perusahaan adalah laporan keuangan. Laporan keuangan bertujuan memberikan informasi tentang posisi keuangan, kinerja dan arus kas perusahaan yang bermanfaat bagi sebagian besar kalangan pengguna laporan dalam rangka membuat keputusan-keputusan ekonomi. Laporan keuangan merupakan pertanggung jawaban manajemen atas penggunaan sumber daya yang dipercayakan kepada mereka. Untuk mencapai tujuan tersebut, laporan keuangan menyajikan keseluruhan informasi mengenai aktiva, kewajiban, ekuitas, pendapatan dan beban, termasuk keuntungan dan kerugian serta arus kas.

Parameter kinerja perusahaan yang menjadi perhatian utama investor dan kreditor adalah arus kas dan laba. Ketika dihadapkan pada dua ukuran kinerja perusahaan tersebut, investor harus merasa yakin bahwa ukuran kinerja yang menjadi perhatian mereka adalah yang mampu secara baik menggambarkan kondisi perusahaan. Laporan arus kas memberikan informasi yang berguna 
tentang penerimaan dan pengeluaran kas selama periode pelaporan. Penerimaan dan pengeluaran kas dalam laporan arus kas disajikan dalam kelompok arus kas dari aktivitas operasi, investasi dan pendanaan. Kandungan informasi arus kas dapat diukur dengan menggunakan kekuatan hubungan antara arus kas dengan return saham. Informasi arus kas akan dikatakan mempunyai makna apabila dengan dipublikasikan laporan arus kas menyebabkan investor bereaksi melakukan pembelian atau penjualan saham yang selanjutnya tercermin dalam harga saham dan return saham, berarti laporan arus kas mempunyai kandungan informasi.

Selain berasal dari laporan arus kas, sumber informasi yang berguna untuk investor dalam pengambilan keputusan juga berasal dari laba akuntansi. Laba akuntansi didefinisikan sebagai kenaikan manfaat ekonomi selama periode akuntansi dalam bentuk penambahan aktiva atau penurunan kewajiban yang mengakibatkan kenaikan ekuitas yang tidak berasal dari kontribusi penanaman modal. Laba akuntansi selain untuk menilai kinerja dapat pula digunakan untuk memprediksi kemampuan laba serta menaksir risiko dalam investasi dan kredit. Penelitian ini menggunakan laba bersih sebagai padanan laba akuntansi. Hal ini dikarenakan laba bersih mendapatkan perhatian lebih banyak daripada bagian laba lainnya dalam laporan keuangan.

Keberadaan informasi laba dan arus kas dipandang oleh pemakai informasi sebagai suatu hal yang saling melengkapi guna mengevaluasi kinerja perusahaan secara keseluruhan. Serangkaian penelitian telah dilakukan untuk menguji reaksi pasar terhadap laporan keuangan perusahaan, namun ditemukan adanya ketidakkonsistensian temuan. Dalam kaitannya pengaruh informasi arus kas operasi terhadap return saham atau keputusan investasi, Rahudiono (2012), Irianti (2008), Kusuma (2005), Khan (2012), Purwaningsih, Susanto dan Martawidjaya (2003), Octora, Shalim dan Petrolina (2003), Kallunki (2000), Hermawan dan Hadyansah (2001), Kusno (2004), dan Triyono dan Jogianto (2000) menyimpulkan adanya pengaruh. Sedangkan Daniati dan Suhairi (2006), dan Naimah (2000) tidak menemukan adanya pengaruh. Dalam kaitannya pengaruh informasi arus kas investasi terhadap return saham atau keputusan investasi, Daniati dan Suhairi (2006), Triyono dan Jogianto (2000), Hermawan dan Hadyansah (2001), Irianti (2008), Kallunki (2000), Kusno (2004), Naimah (2000), Octora, Shalim dan Petrolina (2003) dan Purwaningsih, Susanto dan Martawidjaya (2003) menyimpulkan adanya pengaruh. Dalam kaitannya pengaruh informasi arus kas pendanaan terhadap return saham atau keputusan investasi, Triyono dan Jogianto (2000), Hermawan dan Hadyansah (2001), Irianti (2008), Kallunki (2000), Kusno (2004), Naimah (2000), Purwaningsih, Susanto dan Martawidjaya (2003), dan Octora, Shalim dan Petrolina (2003) menyimpulkan adanya pengaruh. Dalam kaitannya pengaruh informasi laba akuntansi terhadap return saham atau keputusan investasi, Daniati dan Suhairi (2006), Irianti (2008), Kallunki (2000), dan Rahudiono (2012), menyimpulkan adanya pengaruh. Sedangkan Kusuma (2005), Kusno (2004), Naimah (2000) dan tidak menemukan adanya pengaruh.

Penelitian ini bertujuan untuk mengetahui apakah informasi perubahan arus kas dan laba akuntansi digunakan oleh investor untuk mengambil keputusan investasi yang mana hasil keputusan investor akan tercermin dari return saham yang akan diperoleh. Penelitian akan dilakukan pada perusahaan berkapitalisasi besar. Hal ini dikarenakan saham yang memiliki kapitalisasi besar tidak akan mudah digoyahkan oleh para investor yang bertujuan untuk memperoleh keuntungan jangka pendek saja. Pertimbangan lain dalam memilih perusahaan berkapitalisasi besar adalah karena investor dalam perusahaan kapitalisasi besar diasumsikan memiliki tujuan jangka panjang yang dan menerapkan analisis fundamental, yang menggunakan laporan keuangan sebagai dasar analisisnya, bukan perubahan harga.

\section{KAJIAN TEORITIS}

\section{Laporan Arus Kas}

Laporan arus kas merupakan salah satu laporan keuangan yang dipublikasikan. Menurut laporan arus kas melaporkan arus kas masuk dan arus kas keluar yang utama dari suatu perusahaan selama satu periode. Informasi arus kas berguna untuk menilai kemampuan perusahaan dalam menghasilkan kas dan setara kas dan memungkinkan para pengguna mengembangkan model untuk menilai dan membandingkan nilai sekarang dari arus kas masa depan dari berbagai perusahaan (IAI 2009). Penerimaan dan pengeluaran kas dalam laporan arus kas diklasifikasikan menjadi arus kas dari aktivitas operasi, arus kas dari aktivitas investasi, dan arus kas dari aktivitas pendanaan. Pembedaan komponenkomponen arus kas ini sangat penting karena tiaptiap komponen dianggap mempunyai pengaruh dalam pengambilan keputusan penggunanya.

Aktivitas operasi adalah aktivitas penghasil utama pendapatan perusahaan. Jumlah arus kas dari aktivitas operasi merupakan indikator yang menentukan apakah operasi perusahaan dapat 
menghasilkan arus kas yang cukup untuk melunasi pinjaman, memelihara kemampuan operasi perusahaan, membayar dividen dan melakukan investasi baru tanpa mengandalkan sumber pendanaan dari luar. Arus kas dari aktivitas operasi terutama diperoleh dari aktivitas penghasil utama pendapatan perusahaan. Oleh karena itu, arus kas tersebut pada umumnya berasal dari transaksi dan peristiwa lain yang mempengaruhi penetapan laba atau rugi bersih. Aktivitas investasi adalah perolehan dan pelepasan aset jangka panjang serta investasi lain yang tidak termasuk setara kas. Arus kas yang berasal dari aktivitas investasi perlu dilakukan pengungkapan terpisah karena arus kas tersebut mencerminkan penerimaan dan pengeluaran kas sehubungan dengan sumber daya yang bertujuan menghasilkan pendapatan dan arus kas masa depan. Aktivitas pendanaan adalah aktivitas yang mengakibatkan perubahan dalam jumlah serta komposisi modal dan pinjaman perusahaan. Arus kas yang timbul dari aktivitas pendanaan perlu dilakukan pengungkapan terpisah karena berguna untuk memprediksi klaim terhadap arus kas masa depan oleh para pemasok modal perusahaan.

\section{Laba Akuntansi}

Laba adalah jumlah pendapatan yang diperoleh dalam satu periode. Laba akuntansi didefinisikan sebagai perbedaan antara pendapatan yang direalisasi dari transaksi yang terjadi selama satu periode dengan biaya yang berkaitan dengan pendapatan tersebut. Informasi laba sering dilaporkan dalam penerbitan laporan keuangan dan digunakan secara luas oleh pemegang saham dan penanam modal potensial dalam mengevaluasi kemampuan perusahaan. Laba dipakai untuk mengukur efisiensi suatu perusahaan dalam penggunaan sumbe daya ekonomi perusahaan. Ukuran efisiensi umumnya dilakukan dengan membandingkan laba periode berjalan dengan laba periode sebelumnya atau dengan perusahaan lain dengan industri yang sama. Hingga saat ini banyak yang memandang laporan laba rugi akuntansi sebagai informasi terbaik dalam menilai prospek arus kas dimasa depan. Oleh karena itu kualitas laba akuntansi yang dilaporkan oleh manajemen menjadi pusat perhatian pihak eksternal perusahaan. Laba akuntansi yang berkualitas adalah laba akuntansi yang memiliki sedikit atau tidak mengandung gangguan persepsi dan dapat mencerminkan kinerja keuangan perusahaan yang sesungguhnya. Sehingga semakin besar gangguan persepsi yang terkandung dalam laba akuntansi, maka semakin rendah kualitas laba akuntansi tersebut.

\section{Return Saham}

Return saham merupakan pendapatan yang berhak diperoleh investor karena menginvestasikan dananya. Return saham merupakan tingkat keuntungan atau pendapatan yang diperoleh dari investasi surat berharga saham. Return memungkinkan investor untuk membandingkan keuntungan aktual ataupun keuntungan yang diharapkan yang disediakan oleh berbagai investasi pada tingkat pengembalian yang diinginkan. Seorang investor yang rasional akan sangat memperhatikan hasil pengembalian saham karena return saham merupakan salah satu indikator untuk mengetahui keberhasilan suatu investasi.

Faktor yang mempengaruhi return suatu investasi adalah faktor internal perusahaan dan faktor eksternal. Faktor internal perusahaan meliputi kualitas dan reputasi manajemen, struktur permodalan, struktur hutang, tingkat laba yang dicapai dan kondisi intern lainnya di dalam perusahaan. Dan faktor eksternal yang mempengaruhi adalah gejolak politik dalam negeri, perubahan suku bunga tabungan dan deposito, kurs valuta asing, dan inflasi.

Untuk menghitung berapa tingkat return yang dihasilkan dari investasi yang ditanam, dapat menggunakan perhitungan Geometric Mean. Geometric Mean (GM) adalah metode perhitungan rata-rata return terhadap perbandingan harga saham pada saat $t$ dan harga saham t-1 sehingga dapat memperhitungkan compounding return dari investasi tersebut. Harga suatu saham pada hakikatnya ditentukan oleh kekuatan penawaran dan permintaan terhadap saham yang bersangkutan. Kedua kekuatan itu sendiri merupakan pencerminan dari ekpektasi pemodal terhadap kinerja saham di masa yang akan datang (Ajie 2003).

\section{Hubungan Arus Kas dari Aktivitas Operasi terhadap Return Saham}

Arus kas operasi merupakan arus kas yang berasal dari aktivitas penghasil utama pendapatan perusahaan atau transaksi yang masuk atau keluar dari dalam penentuan laba bersih. Meliputi arus kas yang dihasilkan dan dikeluarkan dari transaksi yang masuk determinasi atau penentuan laba bersih (net income). Sehingga makin tinggi arus kas dari aktivitas operasi menunjukkan perusahaan mampu beroperasi secara profitable, karena dari aktivitas operasi saja perusahaan dapat menghasilkan kas dengan baik.

Triyono dan Jogianto (2000) menyimpulkan bahwa pemisahan total arus kas ke dalam tiga komponen arus kas, khusunya arus kas operasi, mempunyai hubungan yang signifikan terhadap harga dan return saham. Livnat dan Zarowin 
(1990) dalam Daniati (2006) yang menguji komponen arus kas menemukan bukti bahwa komponen arus kas mempunyai hubungan yang lebih kuat dengan return saham dibanding hubungan total arus kas dengan return saham. Jumlah arus kas yang berasal dari aktivitas operasi menentukan apakah dari kegiatan operasinya perusahaan dapat menghasilkan arus kas yang cukup untuk melunasi pinjaman, memelihara kemampuan operasi perusahaan, membayar dividen dan melakukan investasi baru tanpa mengandalkan pada sumber pendanaan dari luar. Sehingga adanya perubahan arus kas dari kegiatan operasi yang akan memberikan sinyal positif kepada investor, maka investor akan membeli saham perusahaan yang pada akhirnya meningkatkan return saham. Dari pemikiran dan hasil penelitian tersebut dapat disimpulkan bahwa arus kas dari aktivitas operasi mempunyai hubungan yang positif dengan return saham. Oleh karena itu, hipotesis dapat dirumuskan sebagai berikut:

H1: Perubahan arus kas dari aktivitas operasi berpengaruh positif terhadap return saham

\section{Hubungan Arus Kas dari Aktivitas Investasi terhadap Return Saham}

Arus kas investasi merupakan arus kas yang mencerminkan penerimaan dan pengeluaran kas sehubungan dengan sumber daya yang bertujuan untuk menghasilkan pendapatan. Aktivitas investasi meliputi perolehan dan penjualan investasi serta investasi pada asset jangka panjang yang produktif, seperti pabrik dan peralatan. Termasuk di dalamnya pengunaaan dan perolehan kas untuk penjualan surat hutang atau ekuitas dari kesatuan lain, penjualan dan pembelian harta tetap, penjualan dan pembelian pabrik, peralatan, tanah, dan sebagainya. Sehingga semakin menurunnya arus kas investasi menunjukkan bahwa perusahaan banyak melakukan investasi pada aset tetap atau melakukan pembelian aset investasi. Sebaliknya, semakin meningkatnya arus kas dari aktivitas investasi menunjukkan perusahaan melakukan penjualan aset tetap atau aset investasinya.

Arus kas dari aktivitas investasi dapat menjadi suatu pertimbangan bagi investor untuk menilai kinerja perusahaan di masa depan. Perusahaan dengan arus kas dari aktivitas investasi yang menurun, yang berarti adanya aktivitas investasi, menunjukkan adanya potensi kenaikan pendapatan di masa depat yang diperoleh dari tambahan investasi baru tersebut. Informasi ini tentunya berguna bagi investor dan dapat mempengaruhi keputusan membeli atau menjual saham yang dimilikinya. Keputusan investor ini selanjutnya akan dapat menyebabkan perubahan harga saham dan return saham.

Dari penjelasan di atas, dapat disimpulkan bahwa arus kas dari aktivitas investasi mempunyai hubungan yang negatif dengan tingkat keuntungan saham. Oleh karena itu, hipotesis dapat dirumuskan sebagai berikut:

H2: Perubahan arus kas dari aktivitas investasi berpengaruh negatif terhadap return saham

\section{Hubungan Arus Kas dari Aktivitas Pendana- an terhadap Return Saham}

Arus kas dari aktivitas pendanaan merupakan arus kas yang berguna untuk memprediksi klaim terhadap arus kas masa depan oleh para pemberi dana bagi perusahaan. Aktivitas pendanaan meliputi perubahan pada pos-pos kewajiban jangka panjang dan ekuitas pemilik serta pembayaran deviden kepada pemegang saham. Transaksi pada aktivitas penggunaan dan perolehan kas untuk pembayaran dividen, penerbitan saham biasa, penarikan obligasi, penerbitan utang atau obligasi.

Penerbitan utang merupakan sinyal yang baik untuk menaksir arus kas karena pemilik dapat mempertahankan proporsi kepemilikannya dari pada menerbitkan saham. Berdasar teori ini, pasar akan bereaksi positif terhadap pengumuman penerbitaan hutang. Keputusan pendanaan merupakan signal positif bagi para investor. Investor menjadikan arus kas dari aktivitas pendanaan sebagai tolak ukur dalam menilai perusahaan sehingga akan mempengaruhi keputusan investasi mereka. Selanjutnya keputusan investasi investor akan mempengaruhi permintaan dan penawaran saham perusahaan yang selanjunya akan menyebabkan perubahan harga pasar saham dan return saham.

Dari hasil penjelasan di atas, dapat disimpulkan bahwa arus kas dari aktivitas pendanaan mempunyai hubungan yang positif dengan tingkat keuntungan saham. Oleh karena itu, hipotesis dapat dirumuskan sebagai berikut:

H3: Perubahan arus kas dari aktivitas pendanaan berpengaruh positif terhadap return saham

\section{Hubungan Laba Akuntansi terhadap Return Saham}

Laporan laba rugi merupakan laporan yang mengukur keberhasilan operasi perusahaan dalam suatu periode waktu tertentu. Laporan laba rugi menyediakan informasi bagi investor dan kreditor untuk membantu mereka meramalkan jumlah, waktu, dan ketidakpastian dari arus kas masa depan. Semakin besar laba yang diperoleh perusahaan, maka perusahaan akan mampu mam- 
bagikan dividen yang semakin besar dan akan berpengaruh terhadap return saham secara positif.

Perusahaan yang memiliki kemampuan untuk menghasilkan laba, cenderung harga sahamnya juga akan meningkat. Maksudnya jika perusahaan memperoleh laba yang semakin besar, maka secara teoretis perusahaan akan mampu membagikan dividen yang semakin besar dan akan berpengaruh secara positif terhadap return saham. Penelitian Linda (2005) menyebutkan bahwa peningkatan laba akuntansi dapat mendorong investor untuk lebih tertarik dalam membeli saham perusahaan. Ketertarikan investor untuk membeli saham perusahaan akan dapat meningkatkan harga saham perusahaan dan berujung pada meningkatnya return saham perusahaan. Laba yang tinggi akan mendorong investor untuk membeli saham perusahaan yang bersangkutan karena tertarik akan laba investasi yang lebih tinggi. Ini secara langsung akan mendorong pada peningkatan harga saham dan return saham perusahaan.

Dari penjelasan dan hasil penelitian di atas, dapat disimpulkan bahwa laba akuntansi mempunyai hubungan yang positif dengan tingkat keuntungan saham. Oleh karena itu, hipotesis dapat dirumuskan sebagai berikut:

H4: Perubahan laba akuntansi berpengaruh positif terhadap return saham.

\section{METODE PENELITIAN}

Model analisis yang digunakan untuk menguji hipotesis dalam penelitian ini adalah analisis regresi berganda, sebagai berikut:

$$
\begin{aligned}
& \mathrm{RShm}=\mathrm{a}+81 A K O+B 2 A K I+63 A K P+B 4 N I+\varepsilon \\
& \text { di mana: } \\
& R S h m \text { : variabel terikat (return saham) } \\
& \text { a : konstanta persamaan regresi } \\
& \beta_{1,2,3,4} \text { : koefisien regresi pada setiap variabel } \\
& A K O \text { : perubahan arus kas dari aktivitas operasi } \\
& A K I \text { : perubahan arus kas dari aktivitas inves- } \\
& \text { tasi } \\
& \text { AKP : perubahan arus kas dari aktivitas pen- } \\
& \text { danaan } \\
& \text { NI : laba bersih } \\
& \varepsilon \text { : error }
\end{aligned}
$$

Variabel return saham yang digunakan dalam penelitian ini adalah actual return. Yaitu selisih antara harga saham periode saat ini dengan harga saham pada periode sebelumnya dibagi dengan harga saham periode sebelumnya (capital gain atau loss). Harga saham yang dipakai adalah harga penutupan (closing price) atau harga saham (market value) di Indonesia Stock Exchange (IDX) pada akhir hari perdagangan. Periode pengamat- an perubahan harga saham (event period) yang digunakan adalah 11 hari. Yaitu lima hari sebelum (t-5) hingga lima hari sesudah ( $t+5)$ terjadinya publikasi annual report dan satu hari pada saat dipublikasikannya annual report masing-masing perusahaan. Event period selama 11 hari diambil dengan harapan reaksi pasar sudah dapat terlihat selama periode tersebut. Karena apabila event period yang diambil terlalu panjang dikhawatirkan terdapat informasi lain yang ikut teramati dalam penelitian ini, misalnya pembagian dividen tunai, dividen saham, pemecahan saham (stock split) dan sebagainya.

Variabel arus kas dari aktivitas operasi diukur dari persentase perubahan arus kas dari aktivitas operasi sekarang (t) dikurangi kas yang diperoleh dari kegiatan operasional periode tahun sebelumnya (t-1) dibagi dengan kas yang diperoleh dari kegiatan operasional periode tahun sebelumnya (t-1). Variabel arus kas dari aktivitas investasi diukur dari persentase perubahan arus kas dari aktivitas investasi sekarang (t) dikurangi kas yang diperoleh dari kegiatan investasi periode tahun sebelumnya (t-1) dibagi dengan kas yang diperoleh dari kegiatan investasi periode tahun sebelumnya (t-1). Variabel arus kas dari aktivitas pendanaan diukur dari persentase perubahan arus kas dari aktivitas pendanaan sekarang (t) dikurangi kas yang diperoleh dari kegiatan pendanaan periode tahun sebelumnya (t-1) dibagi dengan kas yang diperoleh dari kegiatan pendanaan periode tahun sebelumnya (t-1). Variabel laba akuntansi diukur dari persentase perubahan laba akuntansi sekarang (t) dikurangi laba akuntansi periode tahun sebelumnya (t-1) dibagi dengan laba akuntansi periode tahun sebelumnya (t-1).

Data yang dipakai dalam penelitian ini adalah laporan keuangan perusahaan yang memiliki kapitalisasi besar yang terdaftar di Bursa Efek Indonesia. Data tersebut dapat diperoleh melalui www.idx.co.id dan www.finance.yahoo.com. Periode laporan keuangan yang dipakai dalam penelitian ini adalah laporan keuangan tahun 2009-2010. Populasi penelitian ini adalah saham yang terdaftar di Bursa Efek Indonesia tahun 2010 yang kemudian diurutkan berdasarkan kapitalisasinya. Terdapat 3 jenis tingkatan dalam kapitalisasi pasar, yaitu: small cap, medium cap, dan big cap. Sampel diambil dengan menggunakan metode purposive sampling. Kriteria pemilihan sampel adalah perusahaan yang terdaftar di Bursa Efek Indonesia tahun 2009-2010 yang memiliki kapitalisasi besar. Dari 420 saham perusahaan yang ada hanya diambil 140 saham perusahaan dengan kapitalisasi paling besar, tetapi setelah ada seleksi sampel jumlah saham perusahaan yang digunakan untuk sampel dalam penelitian ini adalah 97 saham perusahaan. 


\section{HASIL PENELITIAN}

Penelitian dilakukan terhadap 97 perusahaan yang memiliki kapitalisasi besar. Penentuan 97 perusahaan tersebut dilakukan dengan cara terlebih dahulu mengurutkan kapitalisasi seluruh perusahaan yang terdaftar di Bursa Efek Indonesia, kemudian mengambil sepertiganya. Dari langkah ini diperoleh 140 perusahaan. Setelah dilihat kelengkapan datanya, meliputi tanggal publikasi dan harga saham diperoleh 97 perusahaan yang benar-benar lengkap datanya

Dari deskripsi data diketahui nilai rata-rata dari return saham tahun 2009 sebesar 0,0029676 yang berarti investor mendapatkan pengembalian (return) untuk waktu 11 hari periode pengamatan di sekitar tanggal publikasi laporan keuangan sebesar 0,3\%, dengan standar deviasi sebesar 0,00623 atau $0,62 \%$. Nilai maksimum return adalah sebesar $1,98 \%$ yaitu return saham PT Bank Tabungan Pensiunan Nasional (BTPN), sedangkan nilai minimum return sebesar minus 1,05\% terjadi pada saham PT Sumber Alfaria Trijaya Tbk (AMRT). Sedangkan pada tahun 2010 ratarata return saham turun menjadi 0,0013684 dengan standart deviasi sebesar 0,00695. Nilai maksimum return tahun 2010 adalah sebesar $1,78 \%$ yang terjadi pada saham PT Surya Citra Media Tbk (SCMA), sedangkan nilai minimum return sebesar minus 2,03\% terjadi pada saham PT Matahari Department Store Tbk (LPPF).

Tabel 1. Statistik Deskriptif Tahun 2009

Descriptive Statistics

\begin{tabular}{lrrrrr}
\hline \multicolumn{6}{c}{ Descriptive Statistics } \\
\hline AKO & 97 & -989.44 & 20420.78 & 716.6404 & 2929.7121 \\
AKI & 97 & -606355.93 & 312.01 & - & 68404.44783 \\
& & & \multicolumn{1}{c}{10756.8094} & \\
AKP & 97 & 10435.86 & 67691.28 & 696.9628 & 7159.27677 \\
NI & 97 & -4849.35 & 11414.24 & 290.6332 & 1627.33253 \\
Return & 97 & -.01048 & .01977 & .0029676 & .00623150 \\
Valid N & 97 & & & & \\
(listwise) & & & & & \\
\hline
\end{tabular}

Tabel 2. Statistik Deskriptif Tahun 2010

\begin{tabular}{|c|c|c|c|c|c|}
\hline \multicolumn{6}{|c|}{ Descriptive Statistics } \\
\hline & $\mathbf{N}$ & Minimum & Maximum & Mean & 1. Deviation \\
\hline AKO & 97 & -15266.16 & 1582.16 & -213.2371 & 1653.72058 \\
\hline AKI & 97 & -78807.22 & 1596.89 & -1468.3101 & 9264.93807 \\
\hline AKP & 97 & -5007.37 & 5238.82 & 277.' & 1047 \\
\hline NI & 97 & -3510.16 & 2565.40 & 119.6620 & 578.55197 \\
\hline Return & 97 & -.02027 & .01779 & .0013684 & .00695340 \\
\hline $\begin{array}{l}\text { Valid N } \\
\text { (listwise) }\end{array}$ & 97 & & & & \\
\hline
\end{tabular}

Nilai rata-rata perubahan variabel arus kas dari aktivitas operasi (AKO) tahun 2009 sebesar $716,64 \%$, hal ini menunjukkan bahwa perusahaanperusahaan yang menjadi sampel selama tahun 2009 memiliki kenaikkan arus kas dari aktivitas operasi sebesar $716,64 \%$. Nilai maksimum per- ubahan variabel AKO sebesar 20.420,78\% yang terjadi pada saham PT Medco Energi Internasional Tbk (MEDC), sementara nilai minimum dari perubahan variabel AKO sebesar minus 989,44\% terjadi pada PT Energi Mega Persada Tbk (ENRG). Pada tahun 2010 nilai rata-rata variabel arus kas dari aktivitas operasi (AKO) sebesar minus $213,23 \%$. Nilai ini mengalami penurunan yang sangat drastis jika dibandingkan dengan nilai rata-rata AKO tahun 2009. Dimana nilai maksimum perubahan variabel AKO sebesar $1.582,16 \%$ yang terjadi pada saham PT Ultrajaya Milk Industry \& Trading Co Tbk (ULTJ), sementara nilai minimum dari perubahan variabel AKO sebesar negatif $15.266,16 \%$ terjadi pada PT Clipan Finance Indonesia Tbk (CFIN).

Pada tahun 2009 perubahan variabel arus kas dari aktivitas investasi (AKI) memiliki nilai rata-rata negatif $10.756,81 \%$, yang berarti bahwa secara umum perusahaan-perusahaan sampel mengalami arus kas negatif dari aktivitas investasi sebesar $10.756,81 \%$. Nilai maksimum perubahan variabel AKI sebesar 312,01\% pada saham PT Bumi Serpong Damai (BSDE) dan nilai minimum perubahan variabel AKI sebesar negatif 606.355,93\% pada PT Matahari Putra Prima (MPPA). Pada tahun 2010 perubahan variabel arus kas dari aktivitas investasi (AKI) mengalami peningkatan dengan nilai rata-rata minus $1.468,31 \%$. Nilai maksimum perubahan variabel AKI sebesar $1.596,89 \%$ pada saham Bank Danamon Indonesia (BDMN) dan nilai minimum perubahan variabel AKI sebesar -78.807,22\% pada PT Sentul City Tbk (BKSL).

Nilai rata-rata perubahan dari variabel arus kas dari aktivitas pendanaan (AKP) tahun 2009 memiliki rata-rata sebesar 696,96\%, menunjukkan bahwa perusahaan sampel mengalami kenaikan arus kas dari aktivitas pendanaan sebesar $696,96 \%$. Nilai maksimum perubahan variabel AKP sebesar 67.691,27\% terjadi pada saham Bank Tabungan Negara (BBTN) dan nilai minimum dari perubahan variabel AKP sebesar minus 10.435,86\% terjadi pada PT Tunas Ridean Tbk (TURI). Tahun 2010 nilai rata-rata perubahan dari variabel arus kas dari aktivitas pendanaan (AKP) memiliki rata-rata sebesar $277,73 \%$, yang menandakan terjadi penurunan dibandingkan dengan tahun 2009. Nilai maksimum perubahan variabel AKP sebesar $5.238,82 \%$ terjadi pada saham PT Bank Tabungan Negara (BBTN) dan nilai minimum dari perubahan variabel AKP sebesar minus $5.007,37 \%$ terjadi pada Panin Insurance Tbk (PNIN).

Sedangkan tahun 2009 perubahan variabel laba akuntansi (NI) memiliki rata-rata sebesar $290,63 \%$, yang menunjukkan bahwa pada periode 
penelitian perusahaan-perusahaan sampel mengalami peningkatan laba akuntansi sebesar 290,63\%. Nilai maksimum perubahan variabel NI sebesar 11.414,23\% pada saham PT XL Axiata Tbk (EXCL), sementara nilai minimum dari perubahan variabel NI sebesar negatif 4.849,34\% terjadi pada PT Energi Mega Persada Tbk (ENRG). Tahun 2010 terjadi penurunan pada nilai rata-rata NI, yaitu menjadi sebesar $119,66 \%$. Dengan nilai maksimum perubahan variabel NI sebesar $2.565,40 \%$ pada saham PT Sentul City Tbk (BKSL), sementara nilai minimum dari perubahan variabel NI sebesar negatif $3.510,16 \%$ terjadi pada PT Matahari Department Store Tbk (LPPF).

Sebelum pengujian hipotesis dengan regresi berganda, dilakukan pengujian terhadap empat asumsi klasik terlebih dahulu, yaitu: uji normalitas, multikolinearitas, heteroskadisitas dan autokorelasi. Uji normalitas menggunakan uji Kolmogorov Smirnov. Dari 102 perusahaan dalam periode dua tahun, yang dijadikan sampel pada penelitian ini sebanyak 204 data. Uji normalitas pertama menghasilkan data yang tidak normal. Selanjutnya dilakukan analisis data outlier. Terdapat 5 perusahaan yang harus dikeluarkan dari sampel penelitian karena memiliki data outlier, yaitu Bank Pan Indonesia Tbk (PNBN), BW Plantation Tbk (BWPT), Panin Financial Tbk (PNLF), Fastfood Indonesia Tbk (FAST) dan Ciputra Property Tbk (CTRP). Setelah dikeluarkan data yang outlier, diperoleh data yang berdistribusi normal dengan angka significance 0,071 , yang lebih besar dari 0,05 . Pengujian asumsi klasik multikolinearitas dilakukan dengan uji Variace Inflation Factor (VIF). Jika VIF memiliki nilai lebih besar dari 10 maka terjadi multikolinearitas, tetapi bila nilai VIF lebih kecil dari 10 maka tidak ada gejala multikolinearitas. Hasil uji VIF menunjukkan nilai VIF untuk masing-masing variabel bebas adalah 2,130, 2,497, 1,029 dan 1,242 dan hal ini menunjukkan bahwa tidak ada gejala multikolinearitas karena nilai VIF yang telah dihitung lebih kecil dari 10. Pengujian asumsi klasik heteroskedastisitas dilakukan dengan menggunakan metode Spearman's Rank Correlation Test. Hasil pengujian menunjukkan tidak ada nilai masing-masing variabel bebas lebih besar dari 0.05, sehingga dapat disimpulkan tidak ada gejala heteroskedastisitas pada semua variabel bebas. Pengujian autokorelasi dilakukan dengan menggunakan metode Durbin Watson dan kriteria tidak terjadinya autokorelasi adalah jika $\mathrm{du}<$ nilai DW $<4$-du. Nilai du dan dl sendiri dapat diperoleh dari tabel Durbin Watson (Junaidi, 2010) dan dengan melihat signifikasi sebesar 5\%, variabel independen $(\mathrm{k})=4$ dan jumlah sampel (n) = 194 maka didapatkan bahwa nilai $\mathrm{dL}=1.7231$ dan nilai dU = 1.8072 dan kriteria nilai yang tidak mengalami autokorelasi adalah $1.8072<$ nilai DW $<2.1928$. Hasil pengujian menunjukkan nilai DW termasuk dalam kriteria tidak terjadinya autokorelasi yaitu sebesar 1,993 yang berarti tidak terjadi masalah pada autokorelasi.

Hasil pengujian regresi atas variabel-variabel yang diteliti dapat dilihat pada Tabel 3 sampai dengan Tabel 5.

Tabel 3. Nilai R, R Square, SEE untuk Pengujian Hipotesis

Model Summary ${ }^{\mathrm{b}}$

\begin{tabular}{ccccc}
\hline Model & R & R Square & $\begin{array}{c}\text { Adjusted R } \\
\text { Square }\end{array}$ & $\begin{array}{c}\text { Std. Error of the } \\
\text { Estimate }\end{array}$ \\
\hline 1 & $.267^{\mathrm{a}}$ & .071 & .052 & .00645966 \\
\hline
\end{tabular}

a. Predictors: (Constant). NI, AKP, AKO, AKI

b. Dependent Variable: Return

Tabel 4. Uji F dan Signifikansi untuk Pengujian Hipotesis

\begin{tabular}{|c|c|c|c|c|c|}
\hline \multicolumn{6}{|c|}{ ANOVA $^{b}$} \\
\hline Model & $\begin{array}{c}\text { Sum of } \\
\text { Squares }\end{array}$ & $\mathbf{d f}$ & $\begin{array}{c}\text { Mean } \\
\text { Square }\end{array}$ & $\mathbf{F}$ & Sig. \\
\hline 1 Regression & .001 & 4 & .000 & 3.637 & $.007^{\mathrm{a}}$ \\
\hline Residual & .008 & 189 & .000 & & \\
\hline Total & .008 & 193 & & & \\
\hline
\end{tabular}

a. Predictors: (Constant). NI, AKP, AKO, AKI

b. Dependent Variable: Return

Tabel 5. Konstanta, Koefisien Regresi, T-Test dan Signifikasi

\begin{tabular}{lrrrrrr}
\multicolumn{7}{c}{ Coefficients $^{\mathrm{a}}$} \\
\hline \multirow{2}{*}{ Model } & \multicolumn{2}{c}{$\begin{array}{c}\text { Unstandardized } \\
\text { Coefficients }\end{array}$} & $\begin{array}{c}\text { Standardized } \\
\text { Coefficiensts }\end{array}$ & \multirow{2}{*}{ t } & Sig. \\
\cline { 2 - 5 } & \multicolumn{2}{c}{ B } & Std.Error & Beta & & \\
\hline 1 (Constant) & .002 & .000 & & 4.114 & .000 \\
AKO & $1.251 \mathrm{E}-7$ & 000 & .046 & .446 & .656 \\
AKI & $6.644 \mathrm{E}-9$ & 000 & .049 & .442 & .659 \\
AKP & $-1.225 \mathrm{E}-7$ & 000 & -.094 & -1.327 & .186 \\
NI & $1.420 \mathrm{E}-6$ & 000 & .281 & 3.345 & .001 \\
\hline
\end{tabular}

a. Dependent Variable: Return

Dari Tabel 3 dapat terlihat bahwa $\mathrm{R}^{2}$ memiliki nilai sebesar 0,071, yang mana dapat disimpulkan bahwa model regresi mampu menjelaskan pengaruh variabel arus kas operasi, arus kas investasi, arus kas pendanaan dan laba akuntansi terhadap return saham sebesar $7,1 \%$ sedangkan sisanya sebesar 92,9\% tidak dapat dijelaskan oleh persamaan regresi ini atau dengan kata lain banyak faktor lain yang mempengaruhi return saham.

Uji F dilakukan untuk menunjukkan seberapa besar pengaruh arus kas operasi, arus kas investasi, arus kas pendanaan dan laba akuntansi secara bersama-sama terhadap return saham. Hasil uji hipotesis sebagaimana yang dapat dilihat dari Tabel 4. di atas, menunjukkan nilai $\mathrm{F}$ hitung sebesar 3,637 dengan tingkat signifikansi 0,007 
yang berarti lebih kecil dari 0,05. Maka dapat disimpulkan bahwa terbukti ada pengaruh secara bersama-sama antara variabel arus kas operasi, arus kas investasi, arus kas pendanaan dan laba akuntansi terhadap return saham yang diukur dengan menggunakan return geometric mean.

Untuk melihat signifikansi pengaruh parsial masing-masing variabel yaitu variabel arus kas dari aktivitas operasi, arus kas dari aktivitas investasi, arus kas dari aktivitas pendanaan dan laba akuntansi terhadap return saham maka dilakukan uji t. Dari Tabel 5. di atas dapat dijelaskan sebagai berikut: (1) Hipotesis pertama (H1) ditolak karena angka signifikansi sebesar 0,656 yang lebih besar dari 0,05. Hal ini menunjukkan arus kas dari aktivitas operasi tidak berpengaruh terhadap return saham. (2) Hipotesis kedua (H2) ditolak karena angka signifikansi sebesar 0,659 yang juga lebih besar dari 0,05 . Hal ini menunjukkan bahwa arus kas dari aktivitas investasi tidak berpengaruh terhadap return saham. (3) Hipotesis ketiga (H3) juga ditolak karena angka signifikansi sebesar 0,186 yang juga lebih besar dari 0,05. Hal ini menunjukkan bahwa arus kas dari aktivitas pendanaan tidak berpengaruh terhadap return saham. (4) Hipotesis keempat diterima yang ditunjukkan angka koefisien beta positif dan nilai signifikansi sebesar 0,001 yang lebih kecil dari 0,05 . Hal ini berarti terdapat pengaruh positif yang signifikan dari laba akuntansi terhadap return saham.

\section{PEMBAHASAN}

Tujuan utama penelitian ini adalah untuk memperoleh bukti empiris mengenai adanya pengaruh arus kas dari aktivitas operasi, arus kas dari aktivitas investasi, arus kas dari aktivitas pendanaan dan laba akuntansi terhadap return saham pada perusahaan yang memiliki kapitalisasi pasar yang besar. Dari hasil pengujian statistik yang telah dilakukan, dapat dibuktikan bahwa variabel bebas yaitu arus kas dari aktivitas operasi, arus kas dari aktivitas investasi, arus kas dari aktivitas pendanaan dan laba akuntansi secara bersama-sama berpengaruh signifikan terhadap return saham. Namun hasil pengujian tersebut secara parsial menunjukkan bahwa informasi arus kas dari aktivitas operasi, arus kas dari aktivitas investasi, arus kas dari aktivitas pendanaan tidak terbukti mempengaruhi return saham. Sedangkan informasi laba akuntansi terbukti mempengaruhi return saham. Hal ini berarti bahwa investor saham perusahaan yang berkapitalisasi besar tidak mempertimbangkan informasi arus kas dalam mengambil keputusan investasinya. Namun mereka menggunakan infor- masi laba akuntansi untuk mengambil keputusan investasinya. Bukti ini semakin menegaskan bahwa informasi laba akuntansi lebih diperhatikan oleh investor disbanding dengan informasi arus kas. Kinerja perusahaan yang disajikan dalam laporan laba rugi lebih memiliki makna bagi investor dibanding dengan informasi penerimaan dan pengeluaran kas yang disajikan dalam laporan arus kas.

Tidak terbuktinya hipotesis bahwa arus kas dari aktivitas operasi mempengaruhi return saham ini berbeda dengan hasil penelitian Kusno (2004), Rahudiono (2012) dan Khan (2012). Namun hasil penelitian ini sesuai dengan penelitian yang dilakukan oleh Daniati dan Suhairi (2006) yang menyatakan arus kas dari aktivitas operasi tidak memiliki pengaruh yang signifikan terhadap return saham. Hasil penelitian ini menunjukkan bahwa investor tidak melihat pelaporan perubahan arus kas dari aktivitas operasi sebagai informasi yang dapat digunakan untuk pengambilan keputusan investasinya. Arus kas dari aktivitas operasi yang menunjukkan perusahaan mampu beroperasi secara profitable tidak dibaca oleh investor. Jumlah arus kas yang berasal dari aktivitas operasi yang menghasilkan arus kas yang cukup untuk melunasi pinjaman, memelihara kemampuan operasi perusahaan, membayar dividen dan melakukan investasi baru juga tidak dilihat oleh investor dalam mengambil keputusan investasinya. Sehingga adanya perubahan arus kas dari kegiatan operasi yang merupakan sinyal positif kepada investor, tidak tertangkap oleh investor.

Arus kas dari aktivitas investasi juga terbukti tidak berpengaruh terhadap return saham. Investor tidak melihat pelaporan perubahan arus kas investasi tersebut sebagai informasi yang dapat digunakan untuk pengambilan keputusan investasinya. Informasi tentang adanya transaksi investasi yang dilakukan oleh perusahaan, yang selanjutnya akan memperbesar potensi menghasilkan pendapatan di masa depan, ternyata tidak dilihat oleh investor untuk mengambil keputusan investasi.

Arus kas dari aktivitas pendanaan juga terbukti tidak berpengaruh terhadap return saham. Pelaporan arus kas dari aktivitas pendanaan berisi tentang informasi-informasi yang mengakibatkan perubahan dalam jumlah serta komposisi ekuitas dan hutang jangka panjang perusahaan. Investor dalam hal ini tidak melihat pelaporan transaksitransaksi yang merubah komposisi ekuitas dan hutang jangka panjang serta pembayaran dividen tunai sebagai informasi yang dapat digunakan untuk pengambilan keputusan investasinya.

Laba akuntansi terbukti memiliki pengaruh signifikan terhadap return saham. Hasil penelitian 
ini makin memperkuat hasil penelitian yang dilakukan oleh Linda (2005), Martani (2009), Rahudiono (2012) dan juga penelitian Daniati dan Suhairi (2006), bahwa laba akuntansi memliki hubungan positif dengan return saham. Perusahaan yang mempublikasikan laba positif yang tinggi, maka return saham akan tinggi juga. Begitu pula sebaliknya, laba yang buruk akan membuat return saham ikut turun. Informasi laba akuntansi sebagai hasil kinerja perusahaan dibaca oleh investor. Investor terbukti membaca informasi laba akuntansi sebagai salah satu informasi untuk mengambil keputusan investasinya.

\section{KESIMPULAN}

Tujuan penelitian ini adalah untuk mengetahui apakah informasi perubahan arus kas dan laba akuntansi digunakan oleh investor untuk mengambil keputusan investasi yang tercermin dari return saham. Informasi perubahan arus kas dilihat pada tiga komponen, yaitu: arus kas dari aktivitas operasi, arus kas dari aktivitas investasi dan arus kas dari aktivitas pendanaan. Berdasarkan penelitian yang telah dilakukan terhadap perusahaan yang berkapitalisasi besar yang terdaftar di Bursa Efek Indonesia pada tahun 2010, maka didapat hasil bahwa informasi perubahan arus kas di ketiga komponen terbukti tidak berpengaruh secara signifikan terhadap return saham. Sedangkan informasi laba akuntansi terbukti berpengaruh secara signifikan terhadap return saham. Hal ini menunjukkan bahwa informasi laba akuntansi lebih memiliki makna bagi investor dibanding dengan informasi arus kas. Hal ini merupakan tantangan bagi para analis laporan keuangan untuk lebih banyak mengembangkan metode-metode analisis yang menggunakan angka-angka laporan arus kas. Sehingga angkaangka laporan arus kas lebih memiliki makna sebagaimana informasi dalam laporan laba rugi. Tantangan juga bagi penyusun standar untuk terus mengembagkan penyajian laporan arus kas yang lebih mudah dipahami, komunikatif bagi para pengguna laporan keuangan. Sehingga para pengguna laporan keuangan akan juga mulai tertarik untuk melihat angka-angka yang disajikan dalam laporan arus kas, sebagaimana halnya laporan laba rugi.

Keterbatasan data merupakan kendala penelitian ini. Untuk memperoleh informasi laporan keuangan perusahaan, penelitian ini terkendala dengan banyaknya perusahaan yang tidak memiliki data yang lengkap sehingga banyak perusahaan yang seharusnya masuk dalam sampel penelitian harus tereliminasi karena tidak adanya data dan informasi di www.finance.yahoo. com dan web masing-masing perusahaan. Hal ini merupakan tantangan bagi perusahaan publik dan institusi yang mengawasi untuk menjamin ketersediaan data laporan keuangan, yang merupakan kewajiban bagi perusahaan publik untuk mempublikasikan ke masyarakat sebagai pengguna laporan keuangan.

\section{DAFTAR PUSTAKA}

Ajie, V. (2003). Kandungan Informasi Pelaporan Kerugian dan Hubungan dengan Pergerakan Return Saham. Jurnal Riset Akuntansi Indonesia, 6(2), 169-185.

Daniati \& Suhairi (2006). Pengaruh Kandungan Informasi Komponen Laporan Arus Kas, Laba Kotor, dan Size Perusahaan terhadap Expected Return Saham pada Perusahaan Textile dan Automotive di Bursa Efek Jakarta. Makalah Simposium Nasional Akuntansi IX, Padang.

Hermawan \& Hadyansah (2001). Pengaruh Informasi Arus Kas dengan Format Metode Langsung dalam Laporan Arus Kas Terhadap Return Saham. Makalah Simposium Nasional Akuntansi V, Semarang.

Ikatan Akuntan Indonesia (2009). Standar Akuntansi Keuangan - Per 1 Juli 2009. Salemba Empat, Jakarta.

Irianti, T.E. (2008). Pengaruh Kandungan Informasi Arus Kas, Komponen Arus Kas, dan Laba Akuntansi Terhadap Harga dan Return Saham. Tesis. Universitas Diponegoro, Semarang.

Kallunki, J.P. (2000). Stock Market Trading Strategies Based on Earning and Cash Flows in Findland: Alternative Risk-Adjusting Approach. Scandinavian Journal of Management, 16, 85-99.

Khan, W. (2012). Impact of Capital Structure and Financial Performance on Stock Returns: 'A Case of Pakistan Textile Industry'. (June 11, 2012). SSRN: http:// papers.ssrn.com/sol3/papers.cfm?abstract_i $\mathrm{d}=2082306$.

Kusno, J. (2004). Analisis Pengaruh Perubahan Arus Kas dan Laba Akuntansi Terhadap Return Saham pada Perusahaan Go Public di Bursa Efek Jakarta. Tesis. Universitas Diponegoro, Semarang.

Kusuma, P.D.I. (2005). Nilai Tambah Kandungan Informasi Laba dan Arus Kas Operasi. Makalah Simposium Nasional Akuntansi VIII, Solo. 
Linda \& Syam, F. (2005). Hubungan Laba Akuntansi, Nilai Buku, dan Total Arus Kas dengan Market Value: Studi Akuntansi Relevansi Nilai. Jurnal Riset Akuntansi Indonesia, 8(3), September.

Martani, D., Mulyono \& Rahfiani, K. (2009). The Effect of Financial Ratios, Firm Size, and Cash Flow from Operating Activities in the Interim Report to The Stock Return. Chinese Business Review, 8(6), 44-55.

Naimah, Z. (2000). Kandungan Informasi Laba Akuntansi dan Arus Kas terhadap Harga Saham. Jurnal Akuntansi. 4(1), Universitas Tarumanegara, Jakarta.

Octora, Miranda, Salim, Y. \& Petrolina, T.A. (2003). Analisa Pengaruh Kinerja dengan Konsep Konvensional dan Konsep Value Based terhadap Rate of Return. Makalah
Simposium Nasional Akuntansi V. Surabaya, 438-441.

Purwaningsih, E., Susanto, M.H. \& Martawijaya, S. (2003). Analisis Kandungan Informasi Komponen-komponen Arus Kas Operasi, Arus Kas Investasi, Arus Kas Pendanaan dan Pengaruhnya terhadap Return Saham. Jurnal Aplikasi Manajemen, 1(1), 178-179.

Rahudiono, D. (2012). Analysis of The Effect of Accounting Earnings and Operating Cash Flow to Stock Return Manufacturing Companies Listed on Stock Exchange in Indonesia. Students Journal of Accounting and Banking, 1(1).

Triyono \& Hartono, J. (2000). Hubungan Kandungan Informasi Arus Kas, Komponen Arus Kas dan Laba Akuntansi dengan Harga atau Return Saham. Jurnal Riset Akuntansi Indonesia, 3(1), 54-68. 